\title{
Jurist-Diction
}

Volume 4 No. 6, November 202

\section{Prostitusi Online Sebagai Tindak Pidana Perdagangan Orang}

\author{
Afif Fathin Muhtadi \\ Afiffathin21@gmail.com \\ Universitas Airlangga
}

How to cite:

Afif Fathin Muhtadi, 'Prostitusi Online Sebagai Tindak Pidana Perdagangan Orang' (2021)

Vol. 4 No. 6 Jurist-Diction.

Histori artikel:

Submit 7 April 2021;

Diterima 15 Oktober 2021;

Diterbitkan 5 November 2021.

DOI:

10.20473/jd.v4i6.31838

p-ISSN: $2721-8392$

e-ISSN: $2655-8297$

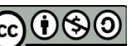

\section{Abstract}

Criminal law in Indonesia specifically does not regulate online prostitution. However, in several court decisions, online prostitution is often linked to the crime of human trafficking because online prostitution involving pimps fulfills the elements of the criminal act of human trafficking as stated in Law No. 21 of 2007 concerning the Eradication of the Crime of human trafficking. This raises the question of what elements cause a pimp can be said to have fulfilled the element of the criminal act of human trafficking and whether sexual consent by a commercial sex worker can erase the criminal element of a pimp. Therefore, in this paper, the authors discuss further the elements of sexual exploitation and consent to victims of human trafficking using online prostitution.

Keywords: Online Prostitution; Human Trafficking; Criminal Act.

\begin{abstract}
Abstrak
Hukum pidana di Indonesia secara khusus tidak mengatur terkait prostitusi secara online. Namun, dalam beberapa putusan pengadilan, prostitusi online sering kali dikaitkan kepada tindak pidana perdagangan orang dikarenakan prostitusi online yang melibatkan muncikari memenuhi unsur-unsur tindak pidana perdagangan orang sebagai mana tercantum dalam Undang-Undang No 21 Tahun 2007 Tentang Pemberantasan Tindak Pidana Perdagangan Orang. Hal tersebut menimbulkan pertanyaan mengenai unsur apa yang menyebabkan seorang muncikari dapat dikatakan telah memenuhi unsur perbuatan tindak pidana perdagangan orang dan apakah persetujuan seksual oleh pekrja seks Komersial dapat menghapus unsur pidana seorang muncikari. Oleh karena itu, dalam penulisan ini, penulis membahas lebih jauh terkait unsur eksploitasi dan persetujuan seksual (sexual consent) terhadap korban tindak pidana perdagangan orang dengan modus prostitusi online.
\end{abstract}

Kata Kunci: Prostitusi Online; Perdagangan Orang; Tindak Pidana. Copyright (C) 2021 Afif Fathin Muhtadi

\section{Pendahuluan}

Perdagangan orang (human trafficking) merupakan tindakan transnasional yang bertentangan dengan harkat dan martabat manusia serta melanggar hak asasi manusia. Perdagangan orang merupakan kejahatan terorganisir secara sistematis, yang dilakukan baik dengan cara-cara konvensional dengan cara bujuk rayu sampai cara-cara modern. 
Salah satu modus dalam tindak pidana perdagangan orang adalah prostitusi, Prostitusi sendiri merupakan suatu pekerjaan menyerahkan diri atau menjual jasa kepada umum untuk melakukan perbuatan perbuatan seksual dengan mendapatkan imbalan sesuai dengan apa yang dijanjikan sebelumnya.

Prostitusi sering dianggap oleh banyak orang sebagai pekerjaan yang dapat menghasilkan banyak uang tanpa harus memikirkan modal dan usaha yang susah. Dikuip dari Liputan6.com, Menurut Havoscope ${ }^{1}$ sebuah perusahaan data pencatat pasar ilegal diseluruh dunia yang melakukan survey pada tahun 2019 mengatakan, bahwa transaksi prostitusi di Indonesia mencapai 2,25 Miliar Dollar Amerika Serikat atau apabila diRupiahkan setara dengan Rp 32.000.000.000.000 (tiga puluh dua triliun rupiah) per tahunnya dimana Indonesia berada di posisi 12 dari seluruh negara di Dunia. angka tersebut bahkan melampaui Taiwan yang mencapai 1,84 Miliar Dollar Amerika Serikat. Di Asia Tenggara sendiri hanya Thailand dan Filipina masing masing diposisi ke 8 dan 9 yang berada di peringkat yang lebih tinggi dari Indonesia, Dilansir dari NET.

Bagi indonesia, sebagai negara berkembang, kasus prostitusi ini tergolong serius, apa lagi dengan diratifikasinya Protokol Palermo melalui Undang-Undang Nomor 14 Tahun 2009 Tentang Pengesahan Protokol Untuk Mencegah, menindak, dan Menghukum Perdagangan Orang, Terutama Perempuan dan Anak-Anak, Melengkapi Konvensi Perserikatan Bangsa-Bangsa Menentang Tindak Pidana Transnasional yang Terorganisasi. Instrumen hukum internasional yang mengatur tentang bentuk kejahatan perdagangan orang ini menyatakan bahwa prostitusi merupakan suatu bentuk eksploitasi terhadap tubuh manusia. ${ }^{2}$ Selain itu penetapan UU No 14 Tahun 2009 itu dilandasi dengan pertimbangan bahwa pada abad ini jutaan anak, baik laki-laki maupun perempuan, telah menjadi korban kejahatan yang sangat luar biasa yang bertentangkan dengan nurani manusia. Peristiwa tersebut

${ }^{1}$ Teddy Tri Setyo Berty, '12 Negara dengan Bisnis Prostitusi Terbesar di Dunia,Ada Nama Indonesia’, (liputan6, 2019)<www.liputan6.com> diakses pada tanggal 3 September 2020.

${ }^{2}$ Ninik Rahayu, 'Logika Hukum Prostitusi dan Perdagangan Manusia' (jalastoria, 2019), <www. jalastoria.id $>$, diakses pada tanggal 13 Agustus 2020. 
juga menjelaskan bahwa kejahatan perdagangan orang, termasuk prostitusi, tidak boleh dibiarkan dan harus mendapat perhatian serius dari pemerintah

Indonesia merupakan salah satu negara pengguna internet terbesar di dunia, oleh karena itu banyak sekali platform media sosial yang bermunculan di Indonesia. Media sosial sangat membantu proses komunikasi anatara individu dengan individu lainnya. Bukan hanya membantu proses komunikasi namun juga membantu percepatan pertumbuhan perekonomian negara. Dengan adanya media sosial ini mempermudahkan pelaku bisnis menjalankan dan mengembangkan bisnisnya. Namun Pada prakteknya, media sosial seperti Whatsapp, Twitter, Facebook, Michat, Line dan lain sebagainya, sering disalah gunakan sebagian orang sebagai media yang mempermudah muckari, penyedia layanan seksual serta pekerja seks komersial dalam menjalankan transaksinya. Ironisnya, sangat banyak para pekerja seks komersial yang menjajalkan diri di dunia maya, mulai dari memasang foto seksi hingga memasang status terang-terangan di profil pibadi. Tujuannya jelas, apalagi kalau bukan untuk menarik calon konsumen. Meski bisnis prostitusi online ini terlihat lebih mudah dalam melakukan transaksi, prostitusi online memiliki resiko kriminalitas yang lebih tinggi bagi kedua belah pihak dibandingkan dengan prostitusi model konvensional.

Sebagai contoh, pada tahun 2015, seorang pekerja seks komersial online bernama Deudeuh Alfisahrin atau yang lebih dikenal dengan nama Tata Chubby, terbunuh. Polisi menemukan petunjuk kuat yang mengarah pada tindak kekerasan yang berujung pembunuhan wanita yang biasa disapa Mpi itu. Pada kasus tersebut ada 7 orang yang dimintai keterangan guna mengungkap kematian Tata chubby. Fakta lain mengungkapkan bahwa Dedeuh alias Tata Chubby aktif berkumandang di Twitter. Dengan akun @tataa_chubby, Ia juga rajin memperbarui statusnya di Blackberry Messenger maupun media sosial lain. Hal ini menjadi petunjuk kuat berikutnya. Aktivitas Deudeuh di media sosial terutama Twitter, menguak informasi yang mengherankan. Tata Chubby diduga sebagai pekerja seks komersial (PSK) yang memanfaatkan dunia maya. Banyak Testimoni dari orang dekat, ditambah kesaksian seorang penjaga kos dan orang dekat Tata Chubby. Kasus ini membuka 
mata publik mengenai akses negatif yang bisa timbul karena prostitusi dapat dengan mudah diakses lewat internet. Pada Kasus tersebut mengungkapkan bahwa bisnis gelap ini memiliki resiko terburuk yaitu pembunuhan.

Prostitusi online memang sering kali dikaitkan kepada tindak pidana yang diatur dalam undang-undang mengenai transaksi elektronik, namun dalam beberapa putusan pengadilan banyak ditemukan kasus prostitusi online yang pelakunya dipidana menggunakan pasal yang diatur dalam Undang-Undang No 21 Tahun 2007 Tindak Pidana Perdagangan Orang (UUPTPPO). Hal tersebut menimbulkan pertanyaan dalam hukum pidana Indonesia, unsur apa yang menyebabkan prostitusi online ini dapat dikaitkan kedalam sebuah tindak pidana perdagangan orang dan apakah persetujuan seksual menjadi suatu alasan hakim menghapuskan unsur pidana pelaku tindak pidana perdagangan orang. Dalam penelitian ini, penulis melakukan analisis terhadap Putusan Pengadilan Negeri Surabaya Nomor 1316/ Pid.Sus/2020/PN.Sby dan Putusan Pengadilan Negeri Jakarta Utara Nomor 205/ Pid.Sus/2019/PN.Jkt.Utr. Dalam melakukan analisis pada penelitian ini, penulis hanya memfokuskan terhadap Unsur eksploitasi pada prostitusi online sebagai suatu kesatuan dari tindak pidana perdagangan orang, serta menganalisis lebih lanjut terkait unsur persetujuan korban atau sexual consent dalam tindak pidana perdagangan orang. Subyek hukum yang penulis bahas dalam analisis ini adalah pihak ketiga yang memfasilitasi bertemunya pelanggan layanan seksual dan pemberi layanan seksual dalam melakukan praktek prostitusi dengan tujuan mendapatkan keuntungan materil atau yang biasa disebut sebagai muncikari dan germo.

\section{Metode Penelitian}

Penelitian ini menggunakan metode penelitianhukum normatif sebagai suatu proses untuk menemukan suatu prinsip-prinsip hukum, aturan hukum, maupun doktrin hukum untuk menjawab permasalahan hukum yang dihadapi. Penelitian hukum normatif dilakukan untuk menghasilkan argumentasi, teori atau konsep 
baru sebagai preskripsi dalam menyelesaikan permasalahan yang dihadapi. ${ }^{3}$ Penelitian ini menggunakan pendekatan kasus (The Case Approach). Pendekatan kasus digunakan sebagai upaya mempelajari penerapan norma-norma yang berlaku dalam suatu hukum positif yang dilakukan dalam praktik atau putusan Pengadilan dengan cara menganalisis kasus yang berkaitan dengan isu hukum yang dijadikan topik pembahasan dalam sebuah tulisan.

\section{Prostitusi Dalam Hukum Positif Di Indonesia}

Prostitusi dalam kamus besar bahasa Indonesia (KBBI) diartikan sebagai pertukaran hubungan seksual dengan uang atau hadiah sebagai suatu transaksi perdagangan atau dengan kata lain disebut pelacuran. Secara etimologi prostitusi berasal dari bahasa latin yaitu "pro-stituere" artinya membiarkan melakukan persundalan, melakukan perzinahan, pergerakan, dan pencabulan, sedangkan kata “prostitute” memiliki arti Wanita Tuna Susila (WTS). Didalam Kamus Besar Bahasa Indonesia WTS adalah wanita celaka yang menjual diri atau orang yang sundal atau disebut sebagai persundalan. Prostitusi juga dapat berarti suatu pekerjaan yang berupa penyerahan diri atau penjualan jasa kepada masyarakat untuk melakukan perbuatan seksual dengan mendapatkan bayaran sesuai perjanjian yang telah dibuat. Wanita Tuna Susila sekarang lebih dikenal sebagai Pekerja Seks Komersial (PSK). Pada prostitusi dikenal beberapa pihak yang terkait langsung pada praktek prostitusi, pihak tersebut antara lain:

\section{Pekerja Seks Komersial/ PSK}

Pekerja Seks Komersial atau biasa disingkat PSK merupakan pekerja yang bertugas melayani aktivitas seksual dengan tujuan mendapatkan uang atau upah dari penerima jasa tersebut. Pada literatur lainnya, disebutkan pengertian PSK adalah seorang wanita yang pekerjaanya menjual diri kepada banyak pria yang membutuhkan pemuasan nafsu seksual, dan wanita tersebut mendapatkan uang sebagai imbalan yang dilakukan diluar pernikahan. Pekerja Seks Komersial

\footnotetext{
${ }^{3}$ Peter Mahmud Marzuki, Penelitian hukum (Prenada Media 2005).[35].
} 
sangat identik dengan pengertian pelacuran, pelacuran merujuk pada perbutannya, sedangkan PSK adalah orang yang melakukannya.

\section{Muncikari/ Germo}

Muncikari atau Gemo (souteneur) dalam pengertian Kamus Besar Bahasa Indonesia diartikan sebagai induk semang bagi perempuan lacur. dalam pengertian lain muncikari adalah orang yang berperan sebagai pengasuh, perantara, dan pemilik PSK.

\section{Pengguna Jasa Seks Komersial}

Pelanggan Pekerja Seks Komersial atau yang lebih dikenal masyarakat sebagai istilah "pria hidung belang" adalah pria yang menggunakan atau membeli jasa layanan seksual dari Pekerja Seks Komersial. Tujuan dari pria hidung belang ini beragam, mulai dari berhubungan badan, hingga sebagai pasangan paruh waktu. Pelanggan Pekerja Seks Komersial ini akan membayarkan uang imbalan atas jasa yang diberikan oleh Pekerja Seks Komersial.

Persoalan prostitusi dalam KUHP, diatur dalam Pasal 506 dan Pasal 296. Ketentuan dalam pasal-pasal ini melarang siapa saja yang menjadikan sebagai mata pencaharian atau kebiasaan dan mengambil keuntungan atas kegiatan cabul yang dilakukan oleh orang lain. Pasal ini ditafsirkan oleh ahli hukum sebagai pasal yang ditujukan untuk para germo, mucikari, atau pengelola rumah bordir. Di dalam hukum pidana umum, tidak ada pasal yang dapat digunakan untuk menjerat pekerja seks komersial maupun pengguna jasa seks komersial. ${ }^{4}$ Pasal yang dapat digunakan untuk menjerat pengguna jasa seks diatur dalam peraturan daerah masing- masing. ${ }^{5}$ Maka berdasarkan dua pasal tersebut dapat ditarik kesimpulan bahwa dalam hukum pidana umum hanya mengatur mengenai muncikari sebagai pihak yang dapat dimintakan pertanggung jawaban pidana.

\footnotetext{
${ }^{4}$ Heman, 'Pengaturan Dan Sistem Penyelesaian Tindak Pidana Prostitusi Online Menurut Hukum Positif' (2017) 130 UIN Alauddin Journal.[132].

5 Sovia Hasanah, 'Pasal Untuk Menjerat Pemakai Jasa PSK' (hukum online, 2018) < www. hukumonline.com> diakses pada tanggal 8 Januari 2021.
} 


\section{Prostitusi Online}

Dalam hukum pidana Indonesia terdapat istilah pelacuran atau prostitusi, namun tidak terdapat istilah prostitusi online. Prostitusi online merupakan perbuatan seksual dengan orang lain yang menggunakan "transaksi" dimana pelaksanaan transaksi tersebut dapat menggunakan media elektronik . Prostitusi online dan Prostitusi konvensional sendiri tidak memiliki perbedaan yang signifikan, yang membedakan adalah proses transaksi seksual pada prostitusi online sepenuhnya/ sebagian menggunakan media sosial/elektronik. Pada prostitusi online, PSK akan mempromosikan diri mereka sendiri melalui media sosial dengan atau tanpa muncikari. pengguna jasa seks kemudian menemukan iklan PSK tersebut lalu terhubung melalui media sosial. Setelah terjadi kesepakatan terkait waktu dan tempat, PSK dan pengguna jasa seks pun bertemu untuk selanjutnya melakukan hubungan seksual.

\section{Pertanggung Jawaban Pidana Prostitusi Online Dalam Hukum Positif Di Indonesia}

Dalam Kitab Undang-Undang Pidana dinyatakan hanya manusia yang dapat melakukan suatu tindak pidana, dan hanya manusia sajalah yang dapat menjadi subyek hukum pidana. Hal ini dapat diketahui dari tiap-tiap pasal di KUHP dimulai dengan kata barangsiapa. Dari kata tersebut, dapat disimpulkan bahwa hanya manusialah yang diakui sebagai subyek tindak pidana, alasan dikatakan demikian karena:

1. Rumusan delik dalam KUHP selalu menggunakan subjek dengan istilah barang siapa, warga negara Indonesia, pegawai negeri, dan lain sebagainya. Hal tersebut dapat dilihat pada pasal 2-9 KUHP;

2. Ketentuan mengenai pertanggungjawaban pidana, terutama pada pasal 44,45 , dan 49 KUHP, yang menggunakan istilah "kejiwaan" dari tindak pelaku;

3. Ketentuan pidana pada pasal $10 \mathrm{KUHP}$ terkait denda, hanya manusialah yang memahami tentang uang.

Selain sifat melawan hukum, unsur kesalahan, yang dalam bahasa Belanda 
disebut sebagai schuld, merupakan salah satu unsur utama yang terkait dengan pertanggungjawaban pelaku atas perbuatannya, termasuk perbuatan pidana atau tindak pidana atau sering disebut sebagai delik . Unsur tersebut dikenal dengan adegium "tidak ada pidana tanpa kesalahan".

Dalam Ketentuan hukum pidana di Indonesia, pengaturan mengenai kejahatan terhadap prostitusi secara online disinggung dalam Pasal 27 ayat (1) Undang-Undang Nomor 11 Tahun 2008 Tentang Informasi dan Transaksi Elektronik (UUITE) jo Undang-Undang Nomor 19 Tahun 2016 dimana disebutkan bahwa : "Setiap Orang dengan sengaja dan tanpa hak mendistribusikan dan/atau mentransmisikan dan/atau membuat dapat diaksesnya Informasi Elektronik dan/atau Dokumen Elektronik yang memiliki muatan yang melanggar kesusilaan". Namun pasal tersebut hanya memberi hukuman bagi mereka yang menyebarluaskan gambar atau konten yang bermuatan asusila saja. Salah satu contoh kasus prostitusi online yang dikenakan pasal 27 Undang-Undang Nomor 27 ayat (1) Undang-Undang No 19 Tahun 2016 Tentang Perubahan Atas 11 Tahun 2008 Tentang Informasi dan Transaksi Elektronik adalah kasus aktris Vanessa Angel di Pengadilan Negeri Surabaya dimana Vanessa divonis hukuman lima bulan penjara setelah dinyatakan bersalah mendistribusikan dan atau mentransmisikan dokumen elektronik yang memiliki muatan melanggar kesusilaan.

Dengan penafsiran sistematis pada KUHP (sebagai ketentuan umum), dapat diketahui bahwa ketentuan dalam Pasal 27 Ayat (1) UUITE melarang aktivitas prostitusi yang dilakukan dengan media elektronik. Penulis berpendapat bahwa pasal 27 ayat 1 UUITE ini mentikberatkan pada konten yang disebarkan menggunakan media elektronik yang dapat menjerat siapa saja yang menyebarluaskannya. Namun terhadap perbuatan pidana prostitusi online tidak menutup kemungkinan jika prostitusi online ini dapat dikaitkan sebagai sebuah tindak pidana perdagangan orang jika pelakunya adalah pihak ketiga, yaitu muncikari atau germo. Berbeda dengan Pasal 27 UUITE jo. Undang-Undang 19 Tahun 2016, dalam halnya prostitusi online pada tindak pidana perdagangan orang, yang dapat diminta pertanggung jawaban hanyalah muncikari atau germo yang melakukan eksploitasi terhadap pekerja seks komersial. 


\section{Keterkaitan Tindak Pidana Perdagangan Orang Dengan Prostitusi Online}

Perdagangan orang menurut pasal 1 angka 1 Undang-Undang Nomor 21 Tahun 2007 Tentang Pemberantasan Tindak Pidana Perdagangan Orang (UUPTPPO) adalah tindakan prekrutan pengangkutan, penampungan, pengiriman, pemindahan, atau penerimaan seseorang dengan ancaman kekerasan, penggunaan kekerasan, penculikan, penyekapan, pemalsuan penipuan, penyalahgunaan kekuasaan atau posisi rentan, penjeratan utang atau memberi bayaran atau manfaat, sehingga memperoleh persetujuan dari orang yang memegang kendali atas orang lain tersebut, baik yang dilakukan di dalam negara maupun antar negara, untuk tujuan eksploitasi atau mengakibatkan orang tereksploitasi. Sedangkan yang dimaksud dengan Tindak Pidana Perdagangan Orang (TPPO) adalah setiap tindakan atau serangkaian tindakan yang memenuhi unsur-unsur tindak pidana yang ditentukan dalam Undang-Undang Nomor 21 Tahun 2007. Dalam UUPTPPO, subjek meliputi:

1. Korban adalah seseorang yang mengalami penderitaan psikis, mental, fisik, seksual, ekonomi,dan/atau sosial, yang diakibatkan tindak pidana perdagangan orang.

2. Setiap orang adalah orang perseorangan atau korporasi yang melakukan tindak pidana perdagangan orang.

Dalam kaitannya dengan prostitusi online, subyek hukum yang penulis angkat dalam penelitian ini adalah orang perseorangan, yaitu muncikari atau germo. Muncikari atau germo berperan sebagi pihak yang memfasilitasi dan sebagai pihak yang turut mendapatkan keuntungan dari praktik prostitusi online dengan cara menampilkan foto-foto berkonten seks korban serta melakukan transaksi yang sepenuhnya atau sebagian dilakukan melalui media sosial/ media daring yang kemudian dengan jasa mempertemukan PSK dengan pelanggan seks tersebut, muncikari atau germo memperoleh imbalan atau keuntungan. Mengambil keuntungan dari pekerja seks komersial oleh muncikari menjadikan perbutan tersebut bertentangan dengan peraturan perundang-undangan . Unsur pidana yang menjerat pelaku tertuang dalam Pasal 2 Ayat (1) UUPTPPO, yang berbunyi, setiap orang yang melakukan perekrutan, pengangkutan, penampungan, pengiriman, 
pemindahan, atau penerimaan seseorang dengan ancaman kekerasan, penggunaan kekerasan, penculikan, penyekapan, pemalsuan, penipuan, penyalahgunaan kekuasaan atau posisi rentan, penjeratan utang atau memberi bayaran atau manfaat walaupun memperoleh persetujuan dari orang yang memegang kendali atas orang lain, untuk tujuan mengeksplkoitasi orang tersebut di wilayah Negara Republik Indonesia, dipidana dengan pidaan penjara paling singkat 3 (tiga) tahun dan paling lama 15 (lima belas) tahun dan denda paling sedikit Rp 120.000.000. (seratus duapuluh juta rupiah) dan paling banyak Rp 600.000.000 (enam ratus juta rupiah). Unsur unsur tersebut dilakukan muncikari untuk mengekploitasi korban dalam hal ini adalah PSK. Perbuatan yang dilakukan muncikari ini juga Sesuai dengan yang disebutkan dalam Pasal 1 ayat (7) dan (8) Undang- Undang Pemberantasan Tindak Pidana Perdagangan Orang tentang pengertian eksploitasi dan eksploitasi seksual. ${ }^{6}$ Unsur-unsur pada Pasal 2 Ayat (1) UUPTPPO tersebut bersifat alternatif, yang berarti jika salah satu unsur perbuatan terpenuhi oleh pelaku, maka unsurunsur dalam pasal tersebut sudah terpenuhi. Apabila kita melihat perbuatan seorang muncikari yang memajang foto atau video PSK melalui media sosial kemudian memfasilitasi ( sebagaimana unsur perbuatan yang tertuang dalam Pasal 2 Ayat (1) UUPTPPO) bertemunya PSK dan pelanggan layanan seksual, penulis berpendapat bahwa sangat dimungkinkan apabila kasus prostitusi online yang dilakukan muncikari dikaitkan sebagai tindak pidana perdagangan orang.

\section{Unsur Eksploitasi dalam Tindak Pidana Perdagangan Orang Yang Berkaitan Dengan Prostitusi Online}

Berdasarkan pasal 2 ayat (1) UUTPPO, Suatu perbuatan dikategorikan sebagai suatu perbuatan tindak pidana perdagangan orang apabila telah memenuhi tiga komponen utama atau unsur yaitu, tindakan/aktivitas, cara, dan tujuan atau maksud eksploitasi.

\footnotetext{
${ }^{6}$ Pasal 1 ayat (8) UUPTPPO : eksploitasi seksual adalah segala bentuk pemanfaatan organ tubuh seksual atau organ tubuh lain dari korban untuk mendapatkan keuntungan, termasuk tetapi tidak terbatas pada semua kegiatan pelacuran atau percabulan.
} 


\section{Tindakan/ Aktivitas}

Merupakan unsur-unsur: tindakan perekrutan, pengangkutan, penampungan, pengiriman, pemindahan, atau penerimaan seseorang. Selaras dengan ketentuan pasal 1 angka 9, maka yang dimaksud sebagai perekrutan adalah tindakan yang meliputi mengajak, mengumpulan, membawa atau memisahkan seseorang dari keluarganya,. Sedangkan pengiriman sesuai dengan pasal 1 angka 10 diartikan sebagai tindakan memberangkatkan seseorang atau melabuhkan seseoarang dari suatu tempat ke tempat lain. Seseorang dikatakan telah memenuhi unsur tindakan atau aktivitas tidaklah harus memenuhi semua unsur dan komponen ini, melainkan cukup apabila salah satu unsur dan komponentindakan/ aktivitas telah terpenuhi.

\section{Cara}

Terdiri atas unsur-unsur: penggunaan kekerasan, ancaman kekerasan penculikan, penyekapan, penipuan, pemalsuan, penyalahgunaan kekuasaan atau posisi rentan, penjeratan utang atau memberi bayaran atau manfaat walaupun memperoleh persetujuan dari orang yang memegang kendali atas orang lain. Berdasarkan ketentuan Pasal 1 angka 12 Undang-Undang Nomor: 21 Tahun 2007 tentang Pemberantasan Tindak Pidana Perdagangan Orang, yang dimaksud dengan ancaman kekerasan adalah setiap perbuatan secara melawan hukum berupa, tulisan, ucapan, simbol, gambar atau gerakan tubuh, baik dengan atau tanpa menggunakan sarana yang menimbulkan rasa takut atau mengekang kebebasan hakiki seseorang. Sedangkan kekerasaan berdasarkan ketetuan Pasal 1 angka 11 Undang-Undang Nomor: 21 Tahun 2007 tentang Pemberantasan Tindak Pidana Perdagangan Orang, diartikan sebagai perbuatan secara melawan hukum, dengan atau tanpa menggunakan sarana terhadap fisik dan psikis yang menimbulkan bahaya bagi badan, nyawa atau menimbulkan terampasnya kemerdekaan seseorang. Penjeratan utang dalam ketentuan Pasal 1 angka 15 Undang-Undang Nomor 21 Tahun 2007 tentang Pemberantasan Tindak Pidana Perdagangan Orang, diartikan sebagai perbuatan menempatkan orang dalam status atau keadaan menjaminkan atau terpaksa menjaminkan dirinya atau keluarganya atau orang-orang yang menjadi jasa pribadinya atau tanggung jawabnya sebagai bentuk pelunasan hutang. Sedangkan 
penyalahgunaan kekuasaan atau posisi rentan diartikan sebagai suatu keadaan dimana terdapat ketidakseimbangan status/kedudukan antara dua pihak (yaitu pelaku dan korban). Pihak yang lebih tinggi memiliki kekuasaan dibanding pihak lainnya yang memiliki kedudukan lebih redah atau berada dalam posisi rentan (misal: majikan dan buruh). Pihak yang memiliki kekuasaan, menyalahgunakan kekuasaannya agar dapat memegang kendali terhadap kerentanan orang lain agar bisa mengeskploitasi orang tersebut. Supriyadi Widodo Eddyono, mengartikan penyalahgunaan kedudukan rentan (abuse of position of vulnerability) sebagai situasi dimana seseorang tidak memiliki pilihan, kecuali untuk pasrah pada penyalahgunaan yang terjadi. unsur cara bersifat alternatif yang berarti Seseorang tidaklah harus memenuhi semua unsur agar unsur tersebut terpenuhi, melainkan cukup apabila salah satu dari komponen cara telah terpenuhi.

3. tujuan/ maksud eksploitasi

Tujuan utama dari tindak pidana perdagangan orang dalam Pasal 2 ayat (1) UUPTPPO maupun Protokol Palermo adalah eksploitasi yang memiliki arti tindakan dengan atau tanpa persetujuan korban yang meliputi, tetapi tidak terbatas pada pelacuran, kerja atau pelayanan paksa ; perbudakan atau praktik serupa perbudakan, pemerasan, penindasan, pemanfaatan fisik, seksual, organ reproduksi, atau secara melawan hukum memindahkan tenaga atau mentransplantasi organ dan/atau jaringan tubuh atau memanfaatkan kemampuan atau tenaga seseorang, oleh pihak lain untuk mendapatkan keuntungan, baik materiil maupun imateriil. Perbudakan menurut pasal 9 Undang-Undang Nomor 26 Tahun 2000 Tentang Pengadilan Hak Asasi Manusia adalah salah satu perbuatan yang dilakukan sebagai bagian dari serangan yang meluas atau sistematik yang diketahuinya bahwa serangan tersebut ditujukan sevara langsung terhadap penduduk sipil.

Didalam Pasal 1 angka 7 UUPTPPO, eksploitasi diartikan sebagai tindakan dengan dan/atau persetujuan tindakan dengan atau tanpa persetujuan korban yang meliputi tetapi tidak terbatas pada pelacuran, kerja atau pelayanan paksa, perbudakan atau praktik serupa perbudakan, penindasan, pemerasan, pemanfaatan fisik, seksual, organ reproduksi, atau secara melawan hukum memindahkan atau 
mentransplantasi organ dan/atau jaringan tubuh atau memanfaatkan tenaga atau kemampuan seseorang oleh pihak lain untuk mendapatkan keuntungan baik materiil maupun immateriil. Apabila seorang muncikari telah melakukan unsur Perbuatan sebagaimana yang disebutkan dalam pasal 2 Ayat (1) UUPTPPO dengan tujuan mengeksploitasi orang tersebut dan memenuhi unsur perbuatan sebagaimana Pasal 1 angka 1 dan 7 UUPTPPO, maka muncikari dapat dikatakan telah memenuhi unsur eksploitasi. Eksploitasi sendiri merupakan tujuan dan akibat dari perdagangan orang. Jika unsur eksploitasi ini tidak dapat dibuktikan, seorang muncikari pada prostitusi online tidak dapat dikatakan sebagai pelaku tindak pidana perdagangan orang.

\section{Pengaruh Persetujuan Seksual Pada Tindak Pidana Prostitusi Online Sebagai Tindak Pidana Perdagangan Orang}

Apabila kita melihat pada Undang-Undang Nomor 21 Tahun 27 Tentang Pemberantasan Tindak Pidana Perdagangan Orang, persetujuan korban bukanlah sebuah alasan penghapus pidana tindak pidana perdagangan orang, sebagaimana tertera pada Pasal 26 UUPTPPO yang berisikan, persetujuan korban perdagangan orang tidak menghilangkan penuntutan tindak pidana perdagangan orang. Sejalan dengan pengertian eksploitasi sebagaimana Pasal 1 angka 7 UUPTPPO dimana terdapat kalimat, "tindakan dengan atau tanpa persetujuan korban", dimana pelaku dalam hal protitusi online adalah muncikari, tetap dapat dituntut pidana atas perbuatan eksploitasi yang dilakukan walaupun telah mendapatkan persetujuan dari korban. Persetujuan seksual menjadi tidak relevan apabila dilakukan dengan cara perekrutan, pengangkutan, pengiriman, penampungan, atau penerimaan orang-orang, dengan ancaman atau penggunaan kekerasan atau bentuk lain dari paksaan, penculikan, penipuan, penyesatan, penyalahgunaan kekuasaan, atau keadaan rentan atau pemberian atau penerimaan pembayaran untuk mendapatkan persetujuan dari seseorang yang memiliki kekuasaan atas orang lain untuk tujuan eksploitasi. Apabila kita kaitkan dengan prostitusi dengan media sosial/ internet, dapat dikatakan bahwa muncikari/germo telah mendapatkan persetujuan dan 
bekerjasama dengan pekerja seks komersial agar PSK tersebut dieksploitasi secara seksual dengan cara menyebarkan foto dan bertransaksi melalui media sosial untuk mengambil keuntungan dari kegiatan seksual tersebut. Persetujuan atau kesepakatan yang dilakukan oleh mucikari dan PSK ini tidak lah sah menurut hukum. Apabila kita melihat pada konsep persetujuan yang terdapat dalam BW Persetujuan atau kesepakatan yang dimaksud adalah sesuai dengan yang tertera dalam pasal 1320 BW, yang memenuhi empat syarat, yaitu:

1. kesepakatan mereka yang mengikatkan dirinya;

2. kecakapan mereka yang mengikatan dirinya;

3. suatu pokok persoalan tertentu;

4. suatu sebab yang tidak dilarang.

Menurut pasal 1355 BW persetujuan tersebut batal demi hukum karena dilaksanakan atas persetujuan tanpa sebab, atau dibuat bedasarkan suatu sebab yang terlarang, tak memilki kekuatan hukum. oleh karena itu persetujuan atau perjanjian antara mucikari dan pekerja seks komersial dikatakan batal demi hukum. kita lihat kembali definisi eksploitasi yang merupakan tindakan dengan atau tanpa persetujuan korban. Terlepas dari tidak sahnya perjanjian, Dapat diketahui bahwa tindakan semacam ini termasuk ke dalam TPPO. Jadi, pelaku tetap dapat dituntut pidana atas perbuatan eksploitasi yang dilakukan walaupun telah mendapatkan persetujuan dari korban.

\section{Kesimpulan}

Tujuanutama dari sebuah tindak pidana perdagangan orang adalah eksploitasi, yaitu dengan mengeksploitasi korban pelaku mendapatkan keuntungan materiel ataupun immateriel. Unsur eksploitasi merupakan penyebab seseorang dinyatakan sebagai pelaku tindak pidana perdagangan orang. Unsur eksploitasi sangat penting dalam mengaitkan prostitusi online dengan tindak pidana perdagangan orang. Tindak pidana prostitusi online dikatakan sebagai tindak pidana perdagangan orang, pertama apabila transaksi dilakukan menggunakan media sosial/media daring. kedua, unsur-unsur yang disebutkan dalam Pasal 1 angka 1 dan 7, serta pasal 2 ayat (1) Undang-Undang Nomor 21 Tahun 2007 Tentang Pemberantasan 
Tindak Pidana Perdagangan Orang yang meliputi tindakan/aktivitas, cara, dengan tujuan eksploitasi harus terpenuhi walaupun hanya satu perbuatan dalam unsur tindakan tersebut yang dilakukan. persetujuan seksual dalam tindak pidana perdagangan orang bukan merupakan alasan penghapus pidana pelaku tindak pidana perdagangan orang.

\section{Daftar Bacaan}

\section{Buku}

Marzuki Peter Mahmud, Penelitian hukum (Prenada Media 2005).

Siregar Kondar, Model Pengaturan Hukum Tentang Pencegahan Tindak Prostitusi Berbasis Masyarakat Adat Dalihan Na Tolu (Perdana Mitra Handalan 2016).

\section{Laman}

Ninik Rahayu, 'Logika Hukum Prostitusi dan Perdagangan Manusia' ( jalastoria, 11 Januari 2019), <https://www.jalastoria.id/logika-hukum-prostitusi-danperdagangan-manusia/> diakses pada tanggal 13 Agustus 2020.

Nathalia Naibaho, prostitusi online dan hukum pidana, ( hukum online, 2019), $<$ https://www.hukumonline.com/berita/baca/lt5c5abece7e335/prostitusionline-dan-hukum-pidana-oleh--nathalina $>$ diakses pada tanggal 4 Septermber 2020.

Sovia Hasanah, 'Pasal Untuk Menjerat Pemakai Jasa PSK' ( hukum online, 2018), <http://app.hukumonline.com/klinik/detail/lt50d13cca972bc/ hukuman-bagi-pembeli-seks $>$. dikunjungi pada tanggal 8 Januari 2021.

Teddy Tri Setyo Berty, '12 Negara dengan Bisnis Prostitusi Terbesar di Dunia,Ada Nama Indonesia' (liputan6 2019) < www.liputan6.com>.

\section{Jurnal}

Heman, 'Pengaturan Dan Sistem Penyelesaian Tindak Pidana Prostitusi Online Menurut Hukum Positif' (2017) UIN Alauddin Journal.

\section{Peraturan Perundang-undangan}

Undang-Undang Nomor 1 Tahun 1946 Tentang Kitab Undang-Undang Hukum Pidana. 

Afif Fathin: Prostitusi Online Sebagai...

Undang-Undang Nomor 21 Tahun 2007 Tentang Pemberantasan Tindak pidana perdagangn Orang.

Undang Undang No 11 Tahun 2008 Tentang Infrmasi dan Transaksi Elektronik. 